\title{
Contribution of Rice Plants and Cover Crop Biomass Amended Soil on Methane Emission
}

\author{
Md Mozammel Haque ${ }^{1,2 *}$, Jatish Chandra Biswas², Muhammad Ashraful Alam1, Pil Joo Kim,3* \\ ${ }^{1}$ Division of Applied Life Science, Gyeongsang National University, Jinju, South Korea \\ ${ }^{2}$ Soil Science Division, Bangladesh Rice Research Institute, Gazipur, Bangladesh \\ ${ }^{3}$ Institute of Agriculture and Life Science, Gyeongsang National University, Jinju, South Korea \\ Email:*mhaquesoil@yahoo.com
}

How to cite this paper: Haque, M.M., Biswas, J.C., Alam, M.A. and Kim, P.J. (2018) Contribution of Rice Plants and Cover Crop Biomass Amended Soil on Methane Emission. American Journal of Climate Change, 7, 477-485.

https://doi.org/10.4236/ajcc.2018.73029

Received: June 21, 2018

Accepted: September 17, 2018

Published: September 20, 2018

Copyright $\odot 2018$ by authors and Scientific Research Publishing Inc. This work is licensed under the Creative Commons Attribution International License (CC BY 4.0).

http://creativecommons.org/licenses/by/4.0/

\section{Open Access}

\begin{abstract}
Rice plant and soil are playing vital role for produce of methane $\left(\mathrm{CH}_{4}\right)$ emission from flooded rice soil. Contribution of rice plants and cover crop biomass amended soil on methane emission has not been yet studied under different cover crop biomass incorporated in paddy fields. Closed-chamber method was used to estimate $\mathrm{CH}_{4}$ emission rates during rice cultivation under soil plus rice plants and soil alone condition. Soil plus rice plants chambers 62 $\times 62 \times 112 \mathrm{~cm}^{3}$ and soil alone chambers $20 \times 20 \mathrm{~cm}^{2}$ were placed at the same time during rice cultivation ( 0 days after rice transplanting). Therefore, to evaluate the contribution of soil plus rice plants and soil alone on methane $\left(\mathrm{CH}_{4}\right)$ emission under different rates of cover crop biomass incorporated soil during rice cultivation. Methane emission from soil plus rice plants increased up to 53 days after transplanting (DAT) and then it's decreased and continued till harvesting. It was found that ca. $47 \%-52 \% \mathrm{CH}_{4}$ was mediated by rice plants and ca. $48 \%$ - 53\% through rice soil alone under $12 \mathrm{Mg} \cdot \mathrm{ha}^{-1}$ cover crop biomass incorporated treated plots. Whereas, only ca. 9\% - $10 \% \mathrm{CH}_{4}$ emission was mediated by rice plants and ca. $90 \%-91 \%$ by rice soil alone when 0 and $3 \mathrm{Mg} \cdot \mathrm{ha}^{-1}$ cover crop biomass was incorporated. Therefore, it could be concluded that rice soil alone was more influenced for $\mathrm{CH}_{4}$ emission than rice plants in paddy fields.
\end{abstract}

\section{Keywords}

Rice Plant, Rice Soil, Methane Emission, Green Manure

\section{Introduction}

Methane, a major component of natural gas is the second most important greenhouse gas (GHG) and the concentration of atmospheric $\mathrm{CH}_{4}$ was 700 $1774 \mathrm{ppb}$ in 2005 [1]. It is the most potent GHG gas with global warming poten- 
tials (GWP) of 25, which is greater than $\mathrm{CO}_{2}$ [1]. Particularly, $\mathrm{CH}_{4}$ is a major issue in flooded rice culture accounting for $10 \%-40 \%$ of the global $\mathrm{CH}_{4}$ emissions [2] [3] [4] and will continue to be a major source as global rice production needs to be increased to feed an ever increasing population, especially in Asian countries [5]. To meet up future demand, annual rice production must to be increased from 520 million tons to at least 880 million tons by 2025 [6].

Methane produced in rice fields by methanogenic bacteria is thought to be released into the atmosphere by different pathways: molecular diffusion at water-air interfaces, ebullition of gas bubbles and plant mediated transport [7]. However, $\mathrm{CH}_{4}$ emission contribution from rice fields have not been yet studied under different cover crop biomass incorporated field conditions. Therefore, the objective of this study was to find out the contribution of rice plants and soil amended with cover crop biomass incorporation rates on $\mathrm{CH}_{4}$ emission in mono rice culture.

\section{Methods}

\subsection{Experimental Field Preparation and Rice Cultivation}

In Korean paddy soil, 140 and $90 \mathrm{~kg} \cdot \mathrm{ha}^{-1}$ of barley and hairy vetch seeds are recommended as a winter cover crop, respectively [8]; but a mixture of $75 \%$ barley and 25\% vetch seeds were sown after rice harvest in 2010 and 2011 at the experimental farm of Gyeongsang National University $\left(36^{\circ} 50^{\prime} \mathrm{N}\right.$ and $\left.128^{\circ} 26^{\prime} \mathrm{E}\right)$, Jinju, South Korea. The selected soil was silt loam in texture and classified as typic Haplaquents with somewhat impeded drainage and organic matter content of $20.4 \pm 3.9 \mathrm{~g} \cdot \mathrm{kg}^{-1}$; soil $\mathrm{pH}\left(1: 5\right.$ with $\left.\mathrm{H}_{2} \mathrm{O}\right), 6.2 \pm 0.32$; available $\mathrm{P}_{2} \mathrm{O}_{5}, 78.7$ $\pm 3.1 \mathrm{mg} \cdot \mathrm{kg}^{-1}$.

In early June of 2011 and 2012, the above-ground biomass of cover crop was harvested manually and yield properties were recorded. Cover crop biomass

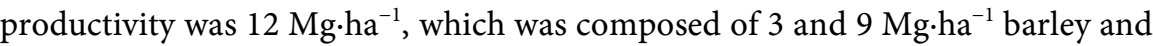
hairy vetch in both the years, respectively. The cover crop mixture contained $42.20 \%$ (wt. $\mathrm{wt}^{-1}$ on dry weight base) total organic C, $2.42 \%$ total N, $17.44 \mathrm{C} / \mathrm{N}$ ratio, cellulose $29.08 \%$, lignin $18.43 \%$, protein $17.06 \%$ and ash $8.4 \%$. Cover crop was chopped into $5-10 \mathrm{~cm}$ size manually and applied at $0,3,6$, and $12{\mathrm{Mg} \cdot h a^{-1}}^{-1}$ as treatments followed by mechanical mixing with surface soil. Randomized complete block design was utilized and treatments were repeated thrice.

Twenty one days old rice (Japonica type) seedlings were transplanted at $15 \mathrm{~cm}$ $\times 30 \mathrm{~cm}$ spacing on 11th and 8th June of 2011 and 2012. The recommended dose of chemical fertilizers ( $\mathrm{N}-\mathrm{P}-\mathrm{K}=90-20-48 \mathrm{~kg} \cdot \mathrm{ha}^{-1}$ ) were applied one day before rice transplanting [9]. Soil was flooded right after biomass incorporation at $5-7 \mathrm{~cm}$ depth, and then this level was maintained during rice cultivation. Water was drained at 21 days before rice harvesting on 21 and 18 October, 2011 and 2012, respectively.

\section{2. $\mathrm{CH}_{4}$ Gas Sampling and Analysis}

A closed-chamber method [10] [11] was used to estimate $\mathrm{CH}_{4}$ emission rates 
during rice cultivation. Closed acrylic column chambers with $20 \mathrm{~cm}$ diameter and $20 \mathrm{~cm}$ height were placed inner soil surface by $20 \mathrm{~cm}$ between rice hills for estimating $\mathrm{CH}_{4}$ emission rates from soil during rice cultivation [12] [13] [14].

\subsection{Soil Sampling and Analysis}

\subsubsection{Estimation of Dissolve Carbons}

Dissolved organic carbon from fresh soil was determined using hot water as described by Ghani et al. [15].

\subsection{2. mcrA and pmoA gene Copy Numbers}

Fresh soil samples were collected at 30 and 70 days after transplanting (DAT) during rice cultivation to compare methanogenic and metanotrophic activities. Soil samples were lyophilized by a Pilot Lyophilizer (PVTFD50A, Ilsin, Korea) and stored at $-70^{\circ} \mathrm{C}$ for analysis. DNA was extracted from the lyophilized soils by a Fast DNA SPIN Kit (MP Biomedical, Santa Ana, CA, USA) following the manufacturer's instruction and was used as a template for quantitative analysis. The real-time quantitative PCR (qPCR) was performed in a BioRad CFX96 real-time thermo-cycler (BioRad Laboratories, Hercules, CA, USA). Reaction mixtures contained $5 \mu$ l of qPCR ROX \& Go Green (qBiogene, Illkirch, France), $1.5 \mu \mathrm{g}$ bovine serum albumin (Sigma-Aldrich, Germany), 5 pmol of each primer [16], 5\% dimethyl sulfoxide (Sigma-Aldrich, Steinheim, Germany), and $0.5 \mu \mathrm{l}$ DNA template and water was added to make the final volume up to $25 \mu \mathrm{l}$ [17]. The amplification was carried out as follows: initial denaturation at $95^{\circ} \mathrm{C}$ for 10 min and 40 cycles at $94^{\circ} \mathrm{C}$ for one min, $52^{\circ} \mathrm{C}$ for one min and $72^{\circ} \mathrm{C}$ for one min. Standard curves were constructed using 10 -fold serial dilutions of plasmids containing a partial sequence of Methanosarcina mazei mcrA gene and Methylocystis sp. SD5 pmoA gene. Amplification efficiencies of the PCRs were calculated using data from the standard curves with the formula: efficiency [10 (-1/slope)] - 1. To minimize the inhibitory effects of co-extracted substances with DNA, amplifications of serial diluted standards were performed for samples of each plot. Four independent assays were run for each sample. The quality of the amplification was evaluated by the generation of melting curves of the PCR products.

\subsection{Statistical Analysis}

Statistical analyses were conducted using SAS software [18]. A one-way ANOVA was carried out to compare the means of different treatments. Fisher's protected least significant difference (LSD) was calculated at 0.05 probability level for making treatment mean comparisons.

\section{Results}

\subsection{Methane Emission through Rice Plants and Soil}

Methane flux was low with 0 and $3 \mathrm{Mg} \cdot \mathrm{ha}^{-1}$ biomass incorporated plots, which was comparable to typical $\mathrm{CH}_{4}$ emission pattern of a general paddy soil (Figure 1). 


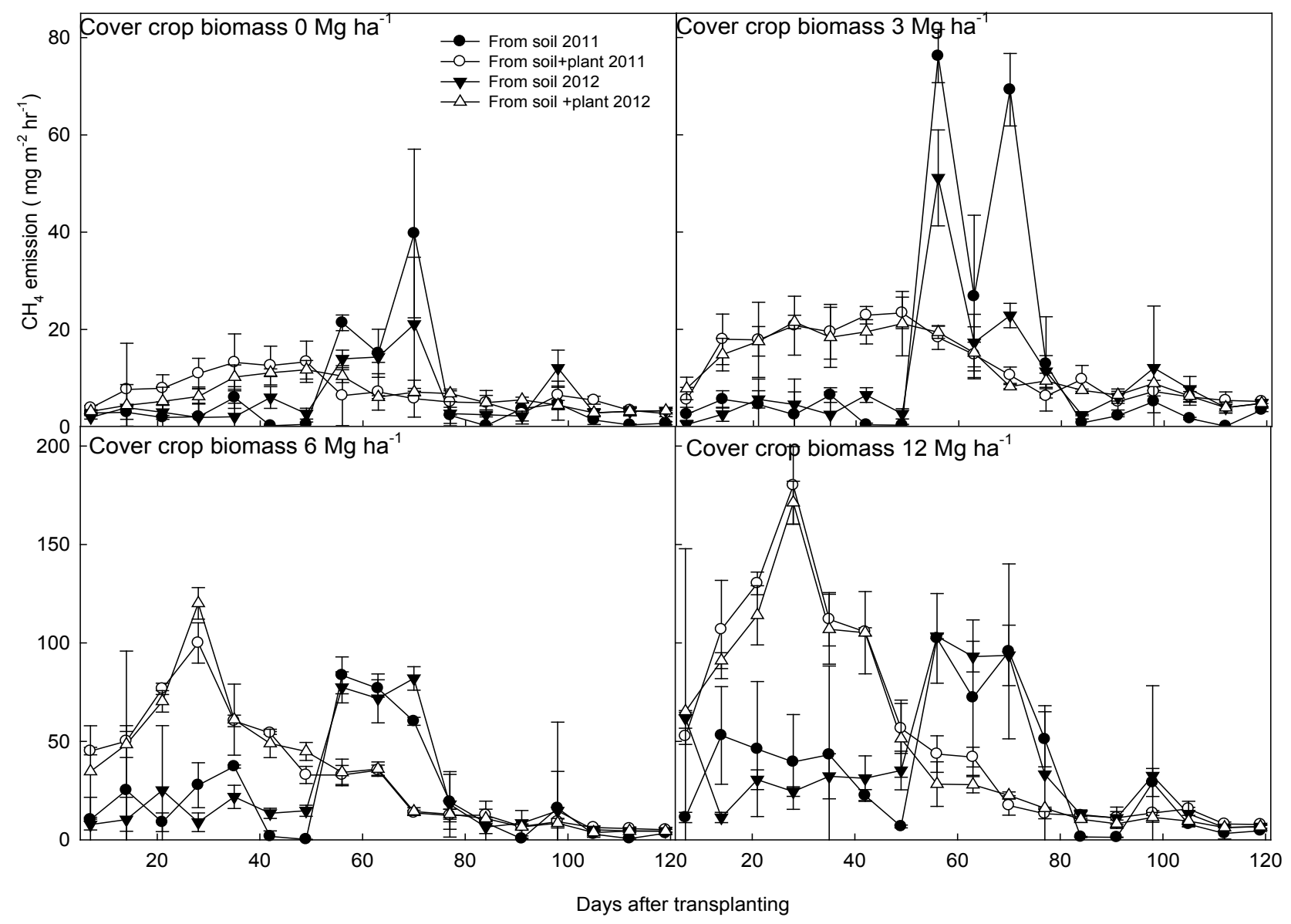

Figure 1. Changes of $\mathrm{CH}_{4}$ emission rates from single soils, and rice planted soils under different cover crop biomass applied condition during rice cultivation.

Methane emission rate was comparatively lower at initial rice growing stage and then increased significantly with the development of soil reductive conditions and plant growth. Higher $\mathrm{CH}_{4}$ emission rates were observed from paddy field

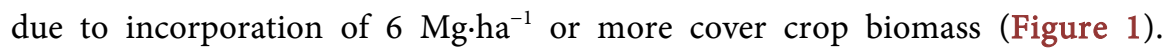
However, the highest peak of $\mathrm{CH}_{4}$ emission was observed at $30 \mathrm{DAT}$ with organic amended soils. For example, more than $77 \%$ of total $\mathrm{CH}_{4}$ was emitted within $50 \mathrm{DAT}$ when $12 \mathrm{Mg} \cdot \mathrm{ha}^{-1}$ biomass was incorporated.

\subsection{Methane Emission through Rice Soil Alone}

In rice soil, $\mathrm{CH}_{4}$ emission rates were lower up to $53 \mathrm{DAT}$ and then gradually increased $\mathrm{CH}_{4}$ in all treatments. Among the treatments, low $\mathrm{CH}_{4}$ emissions were observed in 0 and $3 \mathrm{Mg} \cdot \mathrm{ha}^{-1}$ from rice soil and pattern was not comparable to typical $\mathrm{CH}_{4}$ emission trend of a general paddy field (Figure 1). However, application of higher amount of biomass was responsible for increased $\mathrm{CH}_{4}$ emission. Most $\mathrm{CH}_{4}$ was emitted from rice soil after $53 \mathrm{DAT}$ and the rate sharply increased due to biomass application levels. For example, about $62 \%$ of the total $\mathrm{CH}_{4}$ was emitted under $12 \mathrm{Mg} \cdot \mathrm{ha}^{-1}$ biomass applications after $53 \mathrm{DAT}$. 


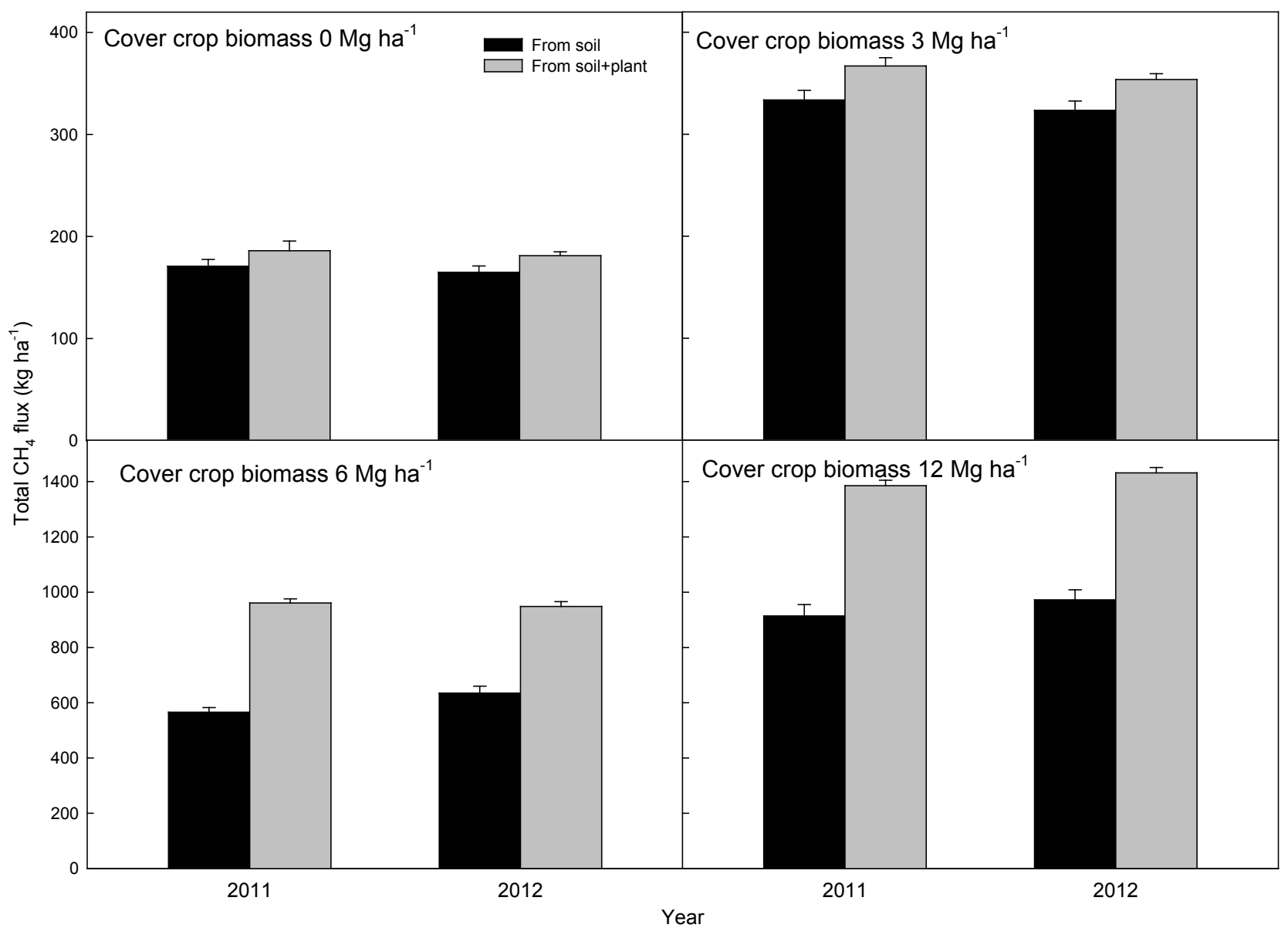

Figure 2. Comparison of total $\mathrm{CH}_{4}$ fluxes during rice cultivation under different cover crop biomass applied condition.

\subsection{Net $\mathrm{CH}_{4}$ Emission}

The contribution of rice plants plus soil on total $\mathrm{CH}_{4}$ flux was $181-186$ and $354-367 \mathrm{~kg} \cdot \mathrm{ha}^{-1}$ and the contribution of rice soil alone was $165-171$ and 324 - $334 \mathrm{~kg} \cdot \mathrm{ha}^{-1}$ with 0 and $3 \mathrm{Mg} \cdot \mathrm{ha}^{-1}$ biomass incorporation in 2011 and 2012, respectively (Figure 2). About $9 \%-10 \% \mathrm{CH}_{4}$ emission was mediated by rice plants and about $90 \%-91 \%$ from rice soil alone in 0 and $3 \mathrm{Mg} \cdot \mathrm{Ma}^{-1}$ treated plots. However, emission rates were $47 \%-52 \%$ through rice plants and $48 \%-53 \%$ from soil alone because higher rate of biomass incorporation in both the years.

\section{Discussion}

At initial rice growth stages, most $\mathrm{CH}_{4}$ emission took place from soil plus rice plants but after 53 DAT its emission was larger from rice soil alone. However, many authors claim that majority of $\mathrm{CH}_{4}$ gas produced in the rice field is emitted through aerenchyma channels and only a little portion is diffused through the soil-water inter-phase of flooded soils [19] [20]. Our results showed that rice plants plus soil emitted $\mathrm{CH}_{4}$ until 53 DAT and then its decreased and continued up to harvesting (Figure 1). At early growth stages, rice roots released more carbon substrates for methanogen activity [21] [22] [23] [24] [25] and thus more 


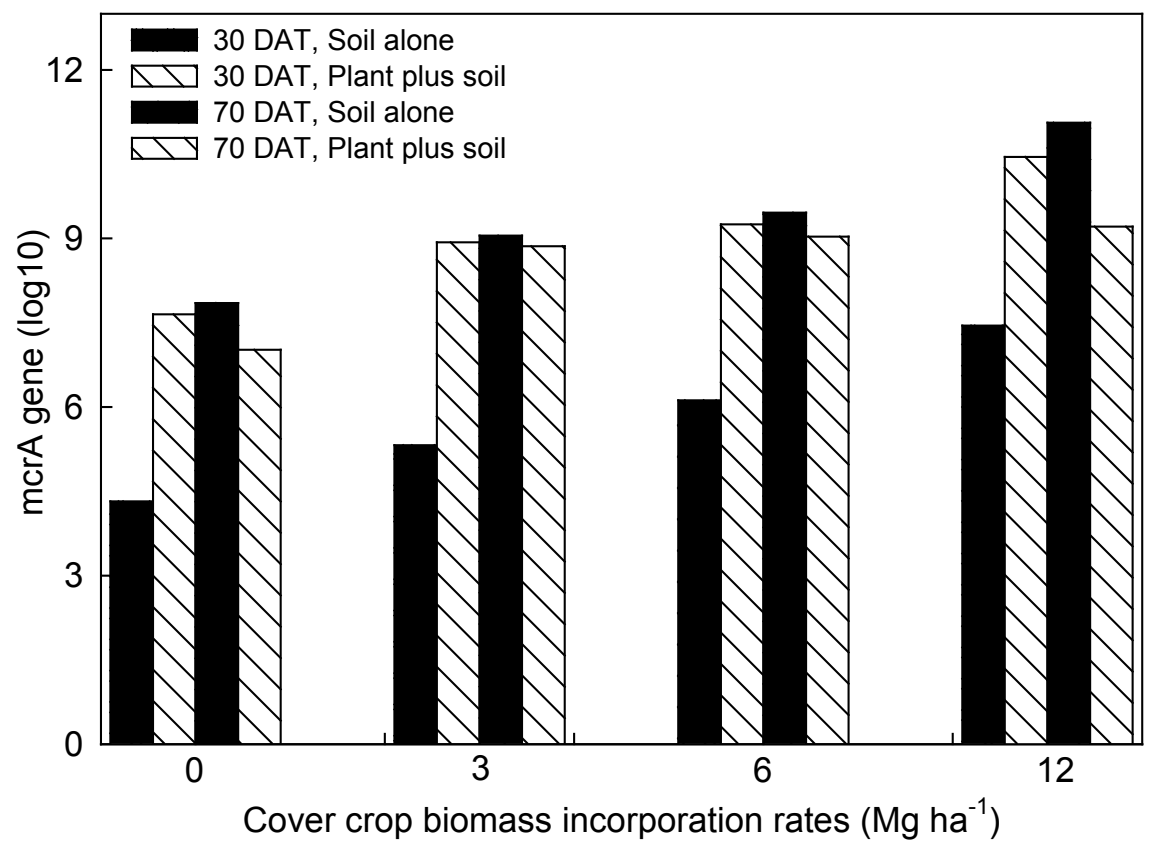

Figure 3. mcrA gene as influenced by different cover crop biomass incorporation on 30th and 70th day after rice transplanting.

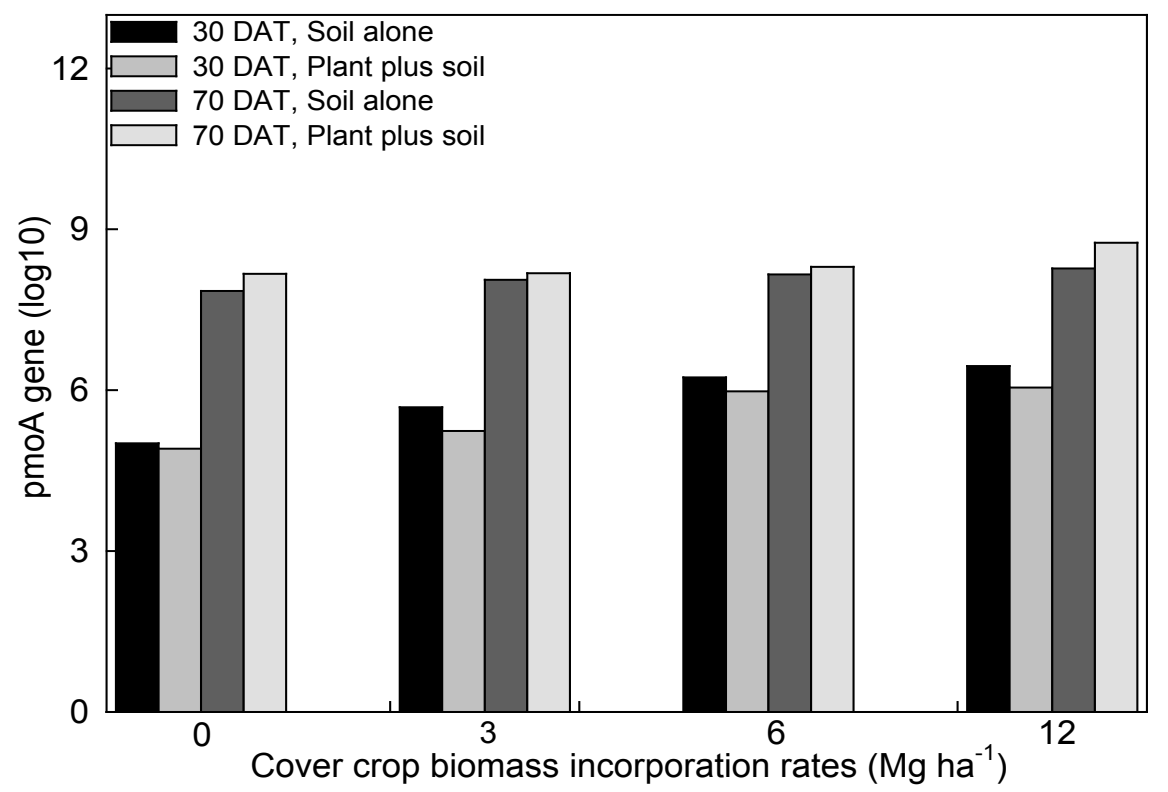

Figure 4. pmoA gene as influenced by different cover crop biomass incorporation on 30th and 70th day after rice transplanting.

$\mathrm{CH}_{4}$ emission takes place (Table 1(a)). At later growth stages, easily available carbon sources reduced [26] and $\mathrm{O}_{2}$ supply increases in the rhizosphere [27] and methanotrophs uses $\mathrm{CH}_{4}$ as terminal electron acceptor for their energy source [28] [29] [30] [31] resulting in emission of $\mathrm{CH}_{4}$ low (Table 1(b)) andmore $\mathrm{CO}_{2}$ from paddy field [32]. The abundance of methanotrophs and methanogens (Figure 3, Figure 4) justifies our statement. 
Table 1. (a) Soil characteristics as influenced by different cover crop biomass incorporation on 30th day after rice transplanting; (b) Soil characteristics as influenced by different cover crop biomass incorporation on 70th day after rice transplanting.

(a)

\begin{tabular}{cccccccccc}
\hline Parameters & \multicolumn{3}{c}{ Soil alone } & \multicolumn{5}{c|}{ Soil plus plant } \\
\hline Biomass application level $\left({\left.\mathrm{Mg} \cdot \mathrm{ha}^{-1}\right)}\right.$ & 0 & 3 & 6 & 12 & 0 & 3 & 6 & 12 \\
$\mathrm{CH}_{4}$ emission rate $\left(\mathrm{g} \cdot \mathrm{m}^{-2}\right)$ & $0.32 \mathrm{~d}$ & $0.76 \mathrm{c}$ & $1.50 \mathrm{~b}$ & $4.12 \mathrm{a}$ & $1.05 \mathrm{~d}$ & $3.61 \mathrm{c}$ & $20.19 \mathrm{~b}$ & $28.78 \mathrm{a}$ \\
DOC $\left(\mathrm{mg} \cdot \mathrm{kg}^{-1}\right)$ & $217 \mathrm{c}$ & $242 \mathrm{~b}$ & $242 \mathrm{~b}$ & $252 \mathrm{a}$ & $244 \mathrm{~d}$ & $251 \mathrm{c}$ & $271 \mathrm{~b}$ & $274 \mathrm{a}$ \\
HWOC $\left(\mathrm{mg} \cdot \mathrm{kg}^{-1}\right)$ & $595 \mathrm{~d}$ & $602 \mathrm{c}$ & $742 \mathrm{~b}$ & $888 \mathrm{a}$ & $914 \mathrm{~d}$ & $994 \mathrm{c}$ & $1057 \mathrm{~b}$ & $1152 \mathrm{a}$ \\
\hline
\end{tabular}

(b)

\begin{tabular}{cccccccccc}
\hline Parameters & \multicolumn{4}{c}{ Soil alone } & \multicolumn{4}{c}{ Soil plus plant } \\
\hline Biomass application level $\left({\left.\mathrm{Mg} \cdot \mathrm{ha}^{-1}\right)}\right.$ & 0 & 3 & 6 & 12 & 0 & 3 & 6 & 12 \\
$\mathrm{CH}_{4}$ emission rate $\left(\mathrm{g} \cdot \mathrm{m}^{-2}\right)$ & $3.54 \mathrm{~d}$ & $3.84 \mathrm{c}$ & $13.77 \mathrm{~b}$ & $15.74 \mathrm{a}$ & $1.16 \mathrm{~d}$ & $1.38 \mathrm{c}$ & $2.41 \mathrm{~b}$ & $3.78 \mathrm{a}$ \\
DOC $\left(\mathrm{mg} \cdot \mathrm{kg}^{-1}\right)$ & $262 \mathrm{~d}$ & $298 \mathrm{c}$ & $338 \mathrm{~b}$ & $420 \mathrm{a}$ & $320 \mathrm{~d}$ & $352 \mathrm{c}$ & $380 \mathrm{~b}$ & $484 \mathrm{a}$ \\
HWOC $\left(\mathrm{mg} \cdot \mathrm{kg}^{-1}\right)$ & $600 \mathrm{~d}$ & $778 \mathrm{c}$ & $803 \mathrm{~b}$ & $994 \mathrm{a}$ & $917 \mathrm{~d}$ & $1022 \mathrm{c}$ & $1132 \mathrm{~b}$ & $1182 \mathrm{a}$ \\
\hline
\end{tabular}

Note: DOC and HWOC mean, dissolved, and hot water extractable organic carbon, respectively.

\section{Conclusion}

Methane emission increased up to 53 DAT from soil plus rice plants and then it decreased and continued up to rice harvesting stage. Our results predicted that about $9 \%-10 \% \mathrm{CH}_{4}$ emission was mediated by rice plants and about $90 \%-91 \%$ by soil alone when 0 and $3 \mathrm{Mg} \cdot \mathrm{ha}^{-1}$ of cover crop biomass was incorporated.

\section{Conflicts of Interest}

The authors declare no conflicts of interest regarding the publication of this paper.

\section{References}

[1] IPCC Climate Change (2007) The Physical Science Basis. Contribution of Working Group I to the Fourth Assessment Report of the Intergovernmental Panel on Climate Change. Cambridge University Press, Cambridge, New York, 996.

[2] Le Mer, J. and Roger, P. (2001) Production, Oxidation, Emission and Consumption of Methane by Soils: A Review. European Journal of Soil Biology, 37, 25-50. https://doi.org/10.1016/S1164-5563(01)01067-6

[3] Chen, Y.H. and Prinn, R.G. (2006) Estimation of Atmospheric Methane Emissions between 1996 and 2001 Using a Three-Dimensional Global Chemical Transport Model. Journal of Geophysical Research, 111, 1-25.

https://doi.org/10.1029/2005JD006058

[4] Dalal, R.C., Allen, D.E., livesley, S.J. and Richards, G. (2008) Magnitude and Biophysical Regulators of Methane Emission and Consumption in the Australian Agricultural, Forest, and Submerged Land Scape: A Review. Plant and Soil, 309, 43-76. https://doi.org/10.1007/s11104-007-9446-7

[5] Minamikawa, K. and Sakai, N. (2006) The Practical Use of Water Management 
Based on Soil Redox Potential for Decreasing Methane Emission from a Paddy Field in Japan. Agriculture Ecosystems and Environment, 116, 181-188. https://doi.org/10.1016/j.agee.2006.02.006

[6] Chang, T. (1984) Conservation of Rice Genetic Resources: Luxury or Necessity? Science, 224, 251-256. https://doi.org/10.1126/science.224.4646.251

[7] Schütz, H., Schroede, R.P. and Rennenberg, H. (1991) Role of Plants in Regulating the Methane Flux to the Atmosphere. In: Sharkey, T.D., Holland, E.A., Mooney, H.A., Eds., Trace Gas Emissions by Plants, Academic Press, San Diego, 29-63. https://doi.org/10.1016/B978-0-12-639010-0.50007-8

[8] Jeon, W.T., Bongsu, C., Abd EL-Azeem, S.A.M. and Yong, S.O. (2011) Effect of Different Seeding Methods on Green Manure Biomass, Soil Properties and Rice Yield in Rice Based Cropping Systems. African Journal of Biotechnoogy, 10, 2024-2031.

[9] RDA (Rural Development Administration) (1999) Fertilization Standard of Crop Plants. National Institute of Agricultural Science and Technology, Suwon, 148.

[10] Rolston, D.E. (1986) Gas Flux. In: Klute, A., Ed., Methods of Soil Analysis, Part 1, 2nd Edition, ASA and SSSA, Madison, WI, 1103-1119.

[11] Haque, M.M., Kim, S.Y., Pramanik, P., Kim, G.Y. and Kim, P.J. (2013) Optimum Application Level of Winter Cover Crop Biomass as Green Manure under Considering Methane Emission and Rice Productivity in Paddy Soil. Biology and Fertility of Soils, 49, 487-493. https://doi.org/10.1007/s00374-012-0766-2

[12] Lou, Y., Li, Z., Zhang, T. and Liang, Y. (2004) $\mathrm{CO}_{2}$ Emissions from Subtropical Arable Soils of China. Soil Biology \& Biochemistry, 36, 1835-1842. https://doi.org/10.1016/j.soilbio.2004.05.006

[13] Xiao, Y., Xie, G., Lu, G., Ding, X. and Lu, Y. (2005) The Value of gas Exchange as a Service by Rice Paddies in Suburban Shanghai, PR China. Agriculture Ecosystems and Environment, 109, 273-283. https://doi.org/10.1016/j.agee.2005.03.016

[14] Iqbal, J., Ronggui, H., Lijun, D., Lan, L., Shan, L., Tao, C. and Leilei, R. (2008) Differences in Soil $\mathrm{CO}_{2}$ Flux between Different Land Use Types in Mid-Subtropical China. Soil Biology \& Biochemistry, 40, 2324-2333. https://doi.org/10.1016/j.soilbio.2008.05.010

[15] Ghani, A., Dexter, M. and Perrott, K. (2003) Hot-Water Extractable Carbon in Soils: A Sensitive Measurement for Determining Impacts of Fertilization, Grazing and Cultivation. Soil Biology \& Biochemistry, 35, 1231-1243. https://doi.org/10.1016/S0038-0717(03)00186-X

[16] Luton, P.E., Wayne, J.M., Sharp, R.J. and Riley, P.W. (2002) The mcrA Gene as an Alternative to 16S rRNA in the Phylogenetic Analysis of Methanogen Populations in Landfill. Microbiology, 148, 3521-3530. https://doi.org/10.1099/00221287-148-11-3521

[17] Ufnar, J.A., Ufnar, D.F., Wang, S.Y. and Ellender, R.D. (2007) Development of a Swine-Specific Fecal Pollution Marker Based on Host Differences in Methanogen mcrA Genes. Applied Environment Microbiology, 73, 5209-5217. https://doi.org/10.1128/AEM.00319-07

[18] SAS Institute (1995) System for Windows Release 6.11. SAS Institute, Cary.

[19] Mariko, S., Harazano, Y., Owa, N. and Nouchi, I. (1991) Methane in Flooded Soil Water and the Emission through Rice Plants to Atmosphere. Environmental and Experimental Botany, 31, 343-350. https://doi.org/10.1016/0098-8472(91)90059-W

[20] Inubushi, K., Muramatsu, Y. and Umebayashi, M. (1992) Influence of Percolation 
on Methane Emission from Flooded Paddy Soil. Japanese Journal of Soil Science and Plant Nutrition, 63, 184-189.

[21] Kimura, M. (1997) Sources of Methane Emitted from Paddy Fields. Nutrient Cycling in Agroecosysts, 49, 153-161. https://doi.org/10.1023/A:1009790920271

[22] Lu, Y.H., Wassmann, R., Neue, H.U. and Huang, C.Y. (2000) Dynamics of Dissolved Organic Carbon and Methane Emissions in a Flooded Rice Soil. Soil Science Society of American Journal, 6, 2011-2017. https://doi.org/10.2136/sssaj2000.6462011x

[23] Cai, Z.C. (1997) A Category for Estimate of $\mathrm{CH}_{4}$ Emission from Rice Paddy Fields in China. Nutrient Cycling in Agroecosysts, 49, 171-179. https://doi.org/10.1023/A:1009729800707

[24] Xu, H., Cai, Z.C., Jia, Z.J. and Tsuruta, H. (2000) Effect of Land Management in Winter Crop Season on $\mathrm{CH}_{4}$ Emission during the Following Flooded and Rice Growing Period. Nutrient Cycling in Agroecosysts, 58, $12-18$. https://doi.org/10.1023/A:1009823425806

[25] Nayak, D.R., Babu, Y.J. and Adhya, T.K. (2007) Long-Term Application of Compost Influences Microbial Biomass and Enzyme Activities in a Tropical Aeric Endoaquept Planted to Rice under Flooded Condition. Soil Biology \& Biochemistry, 39, 1897-1906. https://doi.org/10.1016/j.soilbio.2007.02.003

[26] Gilbert, B. and Frenzel, P. (1998) Rice Roots and $\mathrm{CH}_{4}$ Oxidation: The Activity of Bacteria, Their Distribution and the Micro Environment. Soil Biology \& Biochemistry, 30, 1903-1916. https://doi.org/10.1016/S0038-0717(98)00061-3

[27] Atulba, S.L., Gutierrez, J., Kim, G.W., Kim, S.Y., Khan, M.I., Lee, Y.B. and Kim, P.J. (2015) Evaluation of Rice Root Oxidizing Potential Using Digital Image Analysis. Journal of the Korean Society for Applied Biological Chemistry, 58, 463-471. https://doi.org/10.1007/s13765-015-0042-x

[28] Bodelier, P.L.E., Roslev, P., Henckel, T. and Frenzel, P. (2000) Stimulation by Ammonium-Based Fertilizers of Methane Oxidation in Soil around Rice Roots. Nature, 403, 421-424. https://doi.org/10.1038/35000193

[29] Henckel, T., Roslev, P. and Conrad, R. (2000) Effects of $\mathrm{O}_{2}$ and $\mathrm{CH}_{4}$ on Presence and Activity of the Indigenous Methanotrophic Community in Rice Field Soil. Environmental Microbiology, 2, 666-679. https://doi.org/10.1046/j.1462-2920.2000.00149.x

[30] Macalady, J.L., McMillan, A.M.S., Dickens, A.F., Tyler, S.C. and Scow, K.M. (2002) Population Dynamics of Type I and II Methanotrophic Bacteria in Rice Soils. Environmental Microbiology, 4, 148-157. https://doi.org/10.1046/j.1462-2920.2002.00278.x

[31] Mohanty, S.R., Bodelier, P.L.E., Floris, V. and Conrad, R. (2006) Differential Effects of Nitrogenous Fertilizers on Methane-Consuming Microbes in Rice Field and Forest Soils. Applied Environment Microbiology, 72, 1346-1354. https://doi.org/10.1128/AEM.72.2.1346-1354.2006

[32] Haque, M.M., Kim, S.Y., Kim, G.W. and Kim, P.J. (2015) Optimization of Removal and Recycling Ratio of Cover Crop Biomass Using Carbon Balance to Sustain Soil Organic Carbon Stocks in a Mono-Rice Paddy System. Agriculture Ecosystems and Environment, 207, 119-125. https://doi.org/10.1016/j.agee.2015.03.022 